\title{
'Make the circle bigger': Alternate Discourses of Identity Construction in Black Theologies
}

\author{
Johnathan Jodamus
}

\section{Abstract}

The role and place of South African Black theology in post-apartheid South Africa has been questioned since the advent of democracy in 1994. Recognising that South African Black theology was essentially 'protest theology' against an unjust White government ${ }^{1}$, its utility in a post-apartheid context with a Black government in place, has been questioned. Predominant within this questioning is the political usefulness of Black Theology. What has remained largely un-examined in the literature is a focus on the prefix 'Black' in 'black theology'. It is this that forms the focus of this article. Scrutiny of the prefix 'black' requires a scrutiny of the complexity of racial identity in South Africa. Notwithstanding the ways in which scholars reach for the 'inclusive Biko notion of Black' as a means to almost 'get on' with the political task of black theology, as opposed to debating identity, in this article I argue that critical race and identity theory are central to discussions on resurrecting Black Theologies. I offer a disclaimer that I will not be focusing so much on the matter of theology in this paper, but my focus will be on how identity is racially constructed and I offer suggestions as to how we may begin to think more critically regarding this category within a subject such as black theology. I bring my experiences of being 'Coloured' in South Africa into dialogue with critical identity theorists and argue that we need to 'make the circle bigger,' to include diverse perspectives on identity and that while Spivak's notion of

${ }^{1}$ Mofokeng (May 1988: 34 - 42); Molthabi November 1994: 113 - 141); Maluleke (November 1996: 3 - 19); Tutu 1986: 256 - 64); Maimela (1991: 141 - 59); Mosala (1986); Mosala (1989). 
'strategic essentialism' (i.e. stressing uniformity in blackness) was important in Apartheid South Africa, in post-apartheid South Africa, our ideas of race need to be far more nuanced, if we are to achieve the political ends of Black Theology.

\section{Introduction}

Nou daai's alles well en good en grand ma eintlik issie lot van djulle laat why?

Simply kôs 'n mens figure nie mense daai ways yt kôs vie daai ways praat oor mense issie lewe far te great simply kôs oor mense moet 'n mens praat

net soes ' $n$ mens moet praat oor mense

dja net so

en daa's niks annerste om te glo nie why?

- kôs very simply mense is mense dja, kôs very simply net daai: mense is mense (Small 1973) ${ }^{2}$.

A few years ago I attended a workshop at an institution of higher education in South Africa where I was handed the usual administrative-type mandatory

${ }^{2}$ Adam Small, Oos Wes Tuis Bes: Distrik Ses (Pretoria: Human en Rousseau, 1973). This Afrikaans poem may be translated into English as follows, 'Now that's all well and good and grand but actually the bunch of you are late, why? simply because one does not figure out people that way because for the one who speaks about people in that manner life is far too great simply because we must dialogue about people. Just as one should discuss about people yes just like that and there's nothing else to believe why? because very simply people are people yes, because very simply just that: people are people' (Jodamus English translation of Small, 1973). 
attendance documentation to complete. Whilst filling in the information 'pertinent' to my humanity and identity construction (seeing as I had forgotten my 'dompas' at home $)^{3}$, I filled in other 'crucial' identity signifiers like my title, gender, name and surname. Then I noticed the all too familiar section of racial profiling that has become normative in South Africa. Trepidation set in, mixed with anxiety and a sense of outrage; a feeling of dehumanisation in having to complete this mandatory racial role call trivia. At first I felt obliged to just leave the space set out for this classification blank, as a means of displaying my displeasure, but then I had a brain wave of deviance and wrote in bold print: 'COLOURFUL'. I am indeed a 'subject in process' (Lloyd 2005), am I not? A mixture and multiplicity of performative constructions that, by and of itself, is not limited to fixed ascriptions of 'coloured', 'white', 'black', 'pink' or any other colour under the rainbow, but rather 'COLOURFUL'.

Or maybe it would be best to subscribe to the racial stereotype of being 'Coloured', a descendent possibly of the Khoikhoi or Khoisan people and in accordance with a Nando's television commercial ${ }^{4}$, therefore the only legitimate heir to our beloved South Africa. The Nando's advertisement satirically portrays the elimination of all other South African cultural groups, with the only group who can 'legitimately' claim entitlement to South African soil being the Khoikhoi or Khoisan people and their descendants. If Gilroy (2005) is correct in noting that 'race' is the 'complex, unstable by-product' of racism, then the perpetuation of racial profiling as if race can be neatly packaged in homogenous parcels, is tantamount to a proliferation of racism, and I argue, an internalised reverse-apartheid that is in(habited) in our very constructions of bodiliness (Stoler 1997:183-206). Subscribing to these racial stereotypes merely serves to perpetuate and essentialise 'kyriarchal' (Fiorenza 2001:118-119; Pui-Lan 2005: 86-87; Fiorenza 2007: 84,128) ${ }^{5}$ systems of racial

${ }^{3}$ The literal English translation of this term means 'dumb pass' or 'stupid pass' which was a type of identity document used by the apartheid government to control the movement of black people.

${ }^{4}$ Nando's is a South African dining restaurant food group that specialises in chicken dishes.

5 'Kyriarchy is best theorized as a complex pyramidal system of intersecting multiplicative social structures of superordination and subordination, of ruling and oppression' according to Schüssler Fiorenza (2001: 118). She maintains further that this diagnostic, analytic instrument allows interpreters 'to 


\section{Johnathan Jodamus}

(differ)entiation ${ }^{6}$. While I am all too aware of the importance of these categories for the political ends of redressing imbalances of the past with regard to employment as well as the strategically essentialist move within ideological configurations such as Black and feminist theologies, this awareness did not erase my 'gut discomfort' with the questions. Hence in line with the dictum of liberation theologies that all theologies must begin from experience, I wish to allow this 'gut discomfort' to offer some thoughts with regard to the problem of the perpetuation of fixed identities (Taylor \& Foster 1999: 338-39) ${ }^{7}$, and to problematise those apparently innocent demographical and institutionalised mechanisms, as covert strategies of power transformation

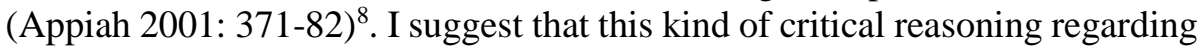
identity construction offers us a useful starting point to talk about the pre-fix 'Black' in Black Theologies. The next few sections will focus on identity construction.

\section{The Complexity, Fluidity and Malleability of Identity(ies)}

Contemporary gender critics and social theorists posit that identity(ies) is a fluid, malleable and discursively formed social construct, created through processes of repetitive performativity (Butler 1993; West \& Zimmeran 2002:

investigate the multiplicative interdependence of gender, race, and class stratifications as well as their discursive inscriptions and ideological reproductions' (Schüssler Fiorenza 2001: 119). For further discussion and critique also see Kwok, Pui-lan (2005:86-87; and Schüssler Fiorenza (2007: $84,128)$.

${ }^{6}$ By writing the term this way I mean to stress the fact that perpetuation of and subscription to these racial stereotypes and race-centric discourses will effectively merely lead to the deferral of this hegemonic ideology to the next generation. The notion of essentialising systems of racial differentiation is gleaned from Perkins Arethusa (1999 198-99).

7 See Rupert Taylor and Don Foster (1999: 338-339) for a suggested hypothesis and strategy of non-racialism in our South African context after the first democratic elections in 1994.

8 For further discussion that highlights the inadequacy of race centric discourses and problematises matters of racial identity and agency see Appiah 2001: 371-382). 
42). According to Castells (2010:6), identity as it refers to social actors may be understood as 'the process of construction of meaning on the basis of a cultural attribute, or related set of cultural attributes, that is/are given priority over other sources of meaning'. This suggests that for any given individual there may be a plethora of identities, as a person may at any given moment choose to give priority to certain sources of cultural attributes over and above others, which will inevitably lead to the construction of a particular identity (Castells 2010:6). Similarly, that same person may at another time give priority of meaning to other sources of cultural attributes, which will inevitably lead to a different construction of identity. Castells (2010:6) departs from using the traditional sociological terms to describe identity, namely, 'roles' and 'role sets', and instead calls for a differentiation of terms (Calhoun 1994:13). Roles, according to Castells (2010:7) 'are defined by norms structured by the institutions and organizations of society. Their relative weight in influencing people's behaviour depends upon negotiations and arrangements between individuals and these institutions and organizations'. Identity, on the other hand is the origins of 'meaning' for individuals, formed through a system of 'individuation' (2010:7). According to this notion, identity may only be regarded as such, if and when individuals 'internalise them, and construct their meaning around this internalisation' $(2010: 7)^{9}$. This seems similar to what Giddens (1991:52) calls 'reflexive awareness'. Giddens (1991:52) maintains that self-identity 'is not something that is just given as a result of the continuities of the individual's action-system, but something that has to be routinely created and sustained in the reflexive activities of the individual'. It should be noted, however, that certain self-definitions of identity may also comply with social roles; an example noted by Castells (2010:7) is, when being a father is the most profound self-definition of identity from the individual's perspective. In this particular situation, it would thus seem as though the person was merely enacting a social role. According to the definition given by Castells (2010:7) however, because this individual has 'internalised' the identity of a father and constructed 'meaning' around this 'internalisation', fatherhood is

\footnotetext{
${ }^{9}$ Castells (2010:7) defines 'meaning' as 'the symbolic identification by a social actor of the purpose of her/his action'. Furthermore, he maintains that 'in the network society' most social actors organise meaning 'around a primary identity (that is an identity that frames the others), which is self-sustaining across time and space'.
} 


\section{Johnathan Jodamus}

therefore, not merely this person's social role but has become an identity.

Identities therefore, from this perspective, are constructed through a dynamic process that consists of 'self-construction and individuation' (2010:7) and 'reflexive awareness' (Giddens 1991:52). Castells (2010:7) argues further that the construction of identity utilises properties 'from history, from geography, from biology, from productive and reproductive institutions, from collective memory and from personal fantasies, from power apparatuses and religious revelations'. He also adds that 'individuals, social groups, and societies process all these materials, and rearrange their meaning, according to social determinations and cultural projects that are rooted in their social structure, and in their space/time framework' (2010:7). These suggestions lead Castells (2010:7) to hypothesise that generally the person 'who constructs collective identity, and for what [purpose], largely determines the symbolic content of this identity, and its meaning for those identifying with it or placing themselves outside of it'. Because the social construction of identity constantly occurs in an environment marked by power relationships, Castells (2010:7-8) postulates a distinction between three types and origins of identity building, namely, 'legitimizing identity', 'resistance identity' and 'project identity'. These may be defined as follows.

First, 'legitimizing identity' is the type of identity introduced by the prevailing institutions of society to enlarge and justify their domination via certain individuals (2010:8). This form of identity building would have been present within what the Kairos document of 1985 refers to as 'State theology' and 'Church Theology'. Second, 'resistance identity' points to the type of identity produced by individuals that are in 'positions/conditions devalued and/or stigmatised by the logic of domination, thus building trenches of resistance and survival on the basis of principles different from, or opposed to, those permeating the institutions of society [...]' (2010:8). This form of identity building would have been present within what the Kairos document termed 'prophetic theologies' out of which arises Black and other liberation theologies. Third, 'project identity' refers to the type of identity that is constructed when individuals, on the grounds of the cultural commodities that are accessible to them, construct a new identity that reshapes their place in society and results in the entire social structure being redefined and transformed (2010:8). These types of 'project identities' is what I would argue is needed as we build viable post-Apartheid theologies. According to Castells (2010:8), identities that begin as 'resistance' identities may generate 'project' 
identities and may also, over time, 'become dominant in the institutions of society', and give rise to 'legitimizing' identities to justify their domination. He further mentions that 'the dynamics of identities along this sequence shows that, from the point of view of social theory, no identity can be an essence, and no identity has, per se, progressive or regressive value outside its historical context' (Castells 2010:8). The latter sentence seems similar to what Foucault (1980: 93-94,97), in his comments on discourse and subjects, has asserted. Foucault $(1985 ; 1986)$ challenged the stability of the individual subject and deconstructed the very notion of gendered and sexual identity. According to Foucault (1991:87-88,94-95) the subject is a historically specific product of discourse with no continuity from one subject to another (Barker 2002:23,24) ${ }^{10}$. In fact Foucault (1991:87-88) states: 'Nothing in man-not even his body - is sufficiently stable to serve as the basis for self-recognition or for understanding other men'. He also maintains that 'history will not discover a forgotten identity, eager to be reborn, but a complex system of distinct and multiple elements, unable to be mastered by the powers of synthesis [...]' (1991:94). Foucault (1997a:87; 1997b:224-225) argues further that one can find different types of 'techniques of the self' in particular historical and cultural situations so that different types of subjects are constituted from different historical and social configurations. The subject, therefore, is exclusively only the product of history. Foucault (1980:98) argues:

The individual is not to be conceived as a sort of elementary nucleus, a primitive atom, a multiple and inert material on which power comes to fasten or against which it happens to strike, and in so doing subdues or crushes individuals. In fact, it is already one of the prime effects of power that certain bodies, certain gestures, certain discourses, certain desires, come to be identified and constituted as individuals. The

${ }^{10}$ Barker (2002: 23) notes that 'Language and discourse do not represent objects or reality but constitute them, bring them into being, so that social reality and social relations are discursively constituted in and through language rather than presented by language'. Barker (2002:24) elaborates more on this understanding of discursive constructions and notes that 'The idea that identities are discursive constructions is underpinned by a view of language in which there are no essences to which language refers and therefore no essential identities'. 


\section{Johnathan Jodamus}

individual, that is, is not the vis-à-vis of power; it is, I believe, one of its prime effects. The individual is an effect of power, and at the same time, or precisely to the extent to which it is that effect, it is the element of its articulation.

Thus, rather than seeing individuals as stable entities, he analyses the discursive processes through which bodies are constituted and maintains that the body is the site on which multiple discourses are enacted and where they are contested (Foucault 1980:93,94,97). He suggests further that the body should be seen as 'the inscribed surface of events', that is, political events and actions have a direct material effect upon the body which can be examined (Foucault 1991:83; Glancy 2010:3-4). He also described the body as 'the illusion of a substantial unity' and 'a volume in perpetual disintegration', thus emphasising that what seems most solid is, in fact, constituted through a multiplicity of discursive processes (Foucault 1991:83). In this regard, because identity is constructed within history (Appiah 2001:373) ${ }^{11}$, that is, it is constructed in a particular time and under particular social and cultural circumstances, it seems apt to describe identity as something that is fluid, dynamic, ambivalent and even precarious. Giddens (1991:53) supports this notion of identity and suggests that self-identity 'is not a distinctive trait, or even a collection of traits, possessed by the individual. It is the self as reflexively understood by the person in terms of her or his biography'. This complies with the assertion made by Barker (2002:17), namely, that 'historically particular modes of production and social relations constitute subjects in specific ways so that what it is to be a person cannot be universal but is located in characteristics of the social formation of definite times and places'.

Lloyd (2005:40) argues for a similar conception of identity and asserts that 'what we are does not precede and shape discourse; rather, it is the effect of discourse'. Lloyd (2005:40) argues further that identity is not a depiction of fundamental characteristics; rather, identity is a 'political construction that presents those characteristics as natural'. Barker (2012:31) goes as far as to

${ }^{11}$ Appiah (2010: 373), also notes the historicity of identity construction(s) and particularly in relation to the notion of an African identity states that the bases through which identity has largely been theorized is premised upon 'a common historical experience' and presupposes 'falsehoods too serious for us to ignore'. 
argue that 'there can be no identity, experience or social practice which is not discursively constructed' because language is inescapable in the production of each of these constructs.

\section{The I(rony)deology of it All}

The above discussion on the contemporary identity debate has demonstrated that the concept of identity(ies) is completely determined by social constructions and social structuring that cannot survive outside of cultural (re)presentations, (re)inscription and language. Given the importance of language to the construction of identity(ies) the statement of Barker (2012:31) that identities are 'not our own, for they are stories constructed from the intersubjective resource of language' seems appropriate. Barker (2012:31) suggests further that 'since the meanings of language are themselves unstable and fluid we can talk of 'identities-in-process' rather than identity' (Lloyd 2005:27, 14-30) ${ }^{12}$. Alluding further to the fluidity of identity, he mentions that when one speaks about identity it intrinsically entails freezing the unstable and multifaceted meanings of language and provisionally stabilising 'the narrative of the self in a cut or strategic positioning of meaning' (2012:31).

Bourdieu (1990:52) posits a theory of 'habitus' by which society perpetuates the status quo through a system of 'structured, structuring dispositions' and habitus generates and navigates the bodyliness of people (Csordas 1994:1-26). It seems apparent in my experiences, mapped out on a 'Coloured' body that new discourses that cater to contemporary challenges need to be articulated and disseminated. We cannot continue to subscribe to andronormative, ethnocentric and hegemonic ideological binaries enforced by 'legitimising identity' (Castells 2010:8) constructions that force us into neatly wrapped packages like the ones we're asked to fill in on mandatory forms seemingly for 'administrative purposes'. I maintain that we need 'resistance

12 Lloyd (2005: 27), argues for a similar understanding of identity and maintains that the subject should be understood as 'ambivalent, in-process, indeterminate, and terminally open to re-inscription; a subject whose identity is always precarious, contingent and ambiguous'. For further discussion of how this notion of the subject relates to feminism and some feminist postulations that feminist politics requires a stable or coherent subject, see Lloyd (2005: 14$30)$. 


\section{Johnathan Jodamus}

identities' and essentially 'project identities' to free us from the stereotypes and racial profiling that perpetuate legitimising identity notions (Castells 2010:7-8). Wanamaker (2003a:194-221; 2003b:115-37) makes explicit the way in which discourses and actions, which carry symbolic meaning, function ideologically to mobilise power in order to either create or maintain domination. He argues that because ideology itself is about power, it is essential firstly to have an adequate definition of power in mind prior to defining the notion of ideology (Wanamaker 2003a:199). Thompson (1990:51) defines power along a continuum consisting of two main aspects. First, power as a general capacity may be regarded as, 'the ability to act in pursuit of one's aims and interests'. This is contingent upon one's location within a particular field of activity or institution. This latter emphasis forms the second main aspect of power and may be defined as:

a capacity which enables or empowers some individuals to make decisions, pursue ends or realise interests; it empowers them in such a way that, without the capacity endowed by their position within a field or institution, they would not have been able to carry out the relevant course (Thompson 1990:151).

In close proximity to power, domination occurs from asymmetrical power relations (Thompson 1990:151; Wanamaker 2003a:199). Such 'systematically asymmetrical' power relations happens when certain people or groups of people are given or take power in a manner that excludes and remains unattainable to other people or groups of people, regardless of the basis upon which such segregation is founded (Thompson 1990:151). Thompson (1990:56) defines ideology as '[T]he ways in which meaning serves to establish and sustain relations of domination'. His concern is with the ways that meaning is utilised by hegemonic individuals and groups to establish and maintain social relations from which they benefit at the expense of other individuals and groups (Thompson 1990:73). Meaning in this context may be construed as the meaning generated by 'symbolic forms' (Thompson 1990:53). According to Thompson (1990:59) this comprises a variety of actions and expressions; images and texts; linguistic expressions (verbal or textual) and non-linguistic or quasi-linguistic expressions such as visual images or constructions that merge images and words not unlike the 'symbolic forms' constituted by the mandatory role call trivia forms discussed earlier. He further 
clarifies that ' $[\mathrm{I}]$ deological phenomena are meaningful symbolic phenomena' when they continue, particularly with regard to socio-historic conditions, to institute and maintain 'relations of domination' (Thompson 1990:56). Keeping in mind Foucault (1980:98) and his assertion that the individual ' $[\mathrm{I}] \mathrm{s}$ not the vis-à-vis of power' but rather is an effect of power and 'the element of its articulation', it seems prudent to observe the interrelationship with power and ideology. I argue - in line with Wanamaker (2003a,2003b) and Thompson (1990) - that ideology is at work where systematically asymmetrical structures of power and domination act upon us from above through institutionalised mechanisms of legitimising identity classifications that serve to subordinate us by and into ideological stereotyping systems and racial profiling. The second wave feminist slogan that the 'personal is political' or vice versa (Enloe 1989:195) rings true once again in the need for us to challenge these normative discourses that perpetuate and re-enforce apartheid legacies of racial discrimination and 'race-centrism'. Enloe (1989:195) laments the disturbance of this slogan in that, ' $[\mathrm{I}] \mathrm{t}$ means that relationships we once imagined were private or merely social are in fact infused with power, usually unequal power backed up by public authority'. Post-1994 and 23 years into a new dispensation of democracy it's about time for the proclamation of new discourses and identity constructions to buttress the assertion of democracy, and for us to jettison the continual racial stereotyping that we see in policies of 'transformation' and Black Economic Empowerment (BEE) ${ }^{13}$.

Prior to 1994 some 'Coloured' people argued that they were not 'white' enough to benefit from the political system of the time ${ }^{14}$. After

\begin{abstract}
${ }^{13}$ Hereafter referred to by the acronym BEE.
${ }^{14}$ I struggle with this term as a fixed descriptor of identity as if it accurately describes the complexity of my identity construction. For the purposes of this paper, however, I use this label as it has been socialised within me and upon me in an effort to queer(y) this meta-narrative and cast aside the fixity of this term as if being 'coloured' is something natural and innate. Similarly as with other terms articulated in this paper that I feel need to be critiqued; I use citation markers as a signifier to note either the satirical nature of my delineation or the uneasiness and internal struggle that accompany the use of these terms for me. For a brief discussion surrounding the debate around 'coloured' identity particularly from the vantage point of the Western Cape and the notion that 'coloured' identity may be understood as constructed, re-constructed, unstable
\end{abstract}




\section{Johnathan Jodamus}

'liberation' and in this democratic dispensation many 'Coloured' people now argue that they are not 'black' enough to benefit from the political system in this new South Africa. This phenomenon seems to have parallels with the notion of 'systematically asymmetrical' power relations as noted earlier, where certain people or groups of people are given or take power, in a manner that excludes and remains unattainable to other people or groups of people. In this case it would appear to be premised merely on racial classification (1990:151). It seems as though 'Coloured' people remain in the proverbial 'middle', juxtaposed between two ideological hegemonic binaries of 'blackness' and 'whiteness'; as if these two social constructs accurately reflect the diversity and heterogeneity that exists within, across, interlocational and translocational positionalities of identities that make up the complexity and fluidity that is South African identity(ies).

\section{New Possibilities - Expanding the Discourse Terrain}

In my first run in with 'the real world' of academic vocation I find myself stuck in the middle of an institutionalised 'kyriarchal' (Fiorenza 2007:118) hegemony that seemingly welcomes and excommunicates people based on their racial, ethnic or sexual identity constructions. People are seemingly welcomed into the 'fold' based almost exclusively on their racial location and expelled or excluded, on this same premise, along similar lines to the Group Areas Act that saw many people forcibly dislodged from their homes and families; or the Population Registration Act and other apartheid policies and ideologies that excluded people based on racial profiling and stereotyping. This may well be a sui generis experience that is far removed from the daily reality of many South Africans and limited to the experience of a novice academic like me. It seems, however, from my limited experience as a 'newbie' academic that this does appear to be the reality of many, if not most people struggling to survive in institutionalised settings that use 'blackness', 'whiteness', 'colouredness' and any other(ness) type of racial stereotyping as a kind of measuring stick that determines mobility, apart from merit.

and heterogeneous see Erasmus and Pieterse (1999: 167-87). Cf., Erasmus and Pieterse (1999:169-171), for a discussion that briefly delineates the history of the term 'coloured'. 
Also, this type of rhetoric and critiquing of these systems seems far removed from the discussion table and is relegated to the dark corners of the tea room, where frightened people attempt to talk about these issues in a manner that is reminiscent of the very same apartheid era that abrogated and silenced freedom of speech and expression. It looks as if this $\mathrm{X}$ and $\mathrm{Y}$ generation has to pay for injustices that were thrust upon our shoulders, whilst those who perpetrated and benefited and continue to benefit from an apartheid system and ideology, sit snug in their offices with pension funds and retirement plans that will see them sitting comfortably at their beach houses in the not too distant future, nostalgically reminiscing on bygone times. Ironically too, and a great challenge for Black theologies is the bourgeois 'black' elite filling their pockets with illegal tenders and riding the money train of capitalism and selfaggrandisement; benefitting from BEE policies that are based upon and seemingly support, essentialist notions of race and identity constructions. Generation $\mathrm{X}$ and $\mathrm{Y}$ who inherit this new politically corrupt dispensation have to stand up and be counted and make their voices heard instead of tacitly being victims of a 'new' ideological system that curtails us and limits us to fabricated racial boxes, doomed to be judged 'once again' by such triviality as the colour of our skins. We need, as Butler (2011:6) asserts 'new possibilities, new ways for bodies to matter'.

In this article I have grappled with how we can construct alternate identity(ies) outside of the constricting parameters of racial profiling and stereotyping that bind us to particular ideologies merely by our bodily locations and 'habituations' instead of identifying us by our humanity? I have tried to suggest the usefulness of these alternate constructions for doing Black theology in post-Apartheid South Africa. If we do not consider these alternatives, I believe that we continue to re-inscribe apartheid ideologies in our own bodiliness by subscribing to racial classification systems and ideologies that were created at a particular juncture and that now appears natural, instead of engaging a notion of 'disidentification' (Butler 1993: xiii) in an attempt to rearticulate identity constructions that serve democracy and de-centres or abjects race centric discourses and race-centrism ${ }^{15}$. The critiquing of this praxis of racial profiling is not intended to denigrate, deny or refute the beauty, complexity and diversity of that which is Black, and that which is known as

${ }^{15}$ Butler (2011: Xiii), mentions that 'the persistence of disidentification is equally crucial to the rearticulation of democratic contestation'. 


\section{Johnathan Jodamus}

'Coloured' culture and identity ${ }^{16}$, as if what it means to be 'Coloured' is inherent to a classification handed down to us by the patriarchal architects and custodians of apartheid. I too am a proud by-product of seemingly traditional 'Coloured' games such as 'seet til seet ${ }^{17}$, kenetjie ${ }^{18}$ and drie blikkies ${ }^{19}$ 'played on the streets of Mitchell's Plain in Cape Town. I too know the discourse, cultural rhetoric and lived reality of 'awe my ma se kind ${ }^{20}$, avaokaarde peere maak die hare mere mamie girl ${ }^{21}$, and eating goema hare or a sucker to make you wakker and n lolly to make you jolly,22.

As Archbishop Emeritus Tutu (1986:256) has reminded us:

Our blackness is an intractable ontological surd. You cannot will it away. It is a brute fact of existence and it conditions that existence as surely as being male or female, only more so. But would we have it otherwise? For it is not a lamentable fact. No, far from it. It is not a lamentable fact because I believe that it affords us the glorious privilege and opportunity to further the gospel of love, forgiveness and reconciliation - the gospel of Jesus Christ in a way that is possible to no other group.

${ }^{16}$ Or any culture for that matter.

${ }^{17}$ This is a popular children's game of hide and seek. Later on I discovered by some friends who lived across the railway tracks that the saying whilst playing the game was apparently not 'seet til seet, nought yet', but actually was 'seek to seek, not yet'.

18 This is a game played by kids using sticks and a cricket bail.

${ }^{19}$ Literally translated from Afrikaans this means 'three cans' and is a game played using tin cans.

${ }^{20}$ A term of endearment which can be translated from Afrikaans to English as 'hello my mother's child'.

${ }^{21}$ Translated from Afrikaans to English this means 'avocado pears makes the hair grow mommy girl' which is a common catch phrase and humorous saying yelled by fruit and vegetable vendors on the Cape flats to gain the attention of prospective customers.

22 Translated from Afrikaans this means 'and eating candy floss or an ice sucker to make you awake' which was and is a common colloquialism screamed by vendors on the streets of the Cape flats or the beaches of Clifton selling ice screams and other sweet treats. 
Conversely, Tinyiko Maluleke (1989: 488) has observed that:

South African black theology was constructed as a 'weapon' with which to engage in the struggle of liberation for the black oppressed and marginalized masses. It was therefore in the crucible of real life struggles rather than in the realm of doctrinal and philosophical orthodoxy that the authenticity and efficacy of black theology was to be judged.

While Tutu called for Blackness to be celebrated within Black theologies and Maluleke showed Blackness to be a weapon within Black theology, this article has asked what other alternatives may exist for how Black identity is constructed. I maintain that, in this democratic dispensation, we need to create new discourses of 'otherness' instead of perpetuating the dominant rhetoric of a bygone apartheid regime.

'Otherness' taken in this way, suggests the liberation from essentialism, of which the fixities form the bases for rigid identities. Can we have true resistance of hegemonic discourses and ideologies without inversion or jettisoning these hegemonic constructions? It may be true that resistance to and of, dominant transcripts may be undertaken through compliance with or assimilation of, such discourses by means of subversive transcripts as Scott asserts (1990:102f). However, this strategy seems more apt in an environment that is resistant to freedom and equality, not one in which freedom and equality is enshrined, as in democratic South Africa. Deconstruction, as Butler demonstrates (1993:5), does not mean eradication and certainly does not necessitate the uselessness of certain cultural articulations, but rather critiques and interrogates 'the exclusionary operations and differential power-relations that construct and delimit' discursive categories such as 'Coloured'. Butler (1993:6) in a very different context comments further:

To call a presupposition into question is not the same as doing away with it; rather, it is to free it from its metaphysical lodgings in order to understand what political interests were secured in and by that metaphysical placing, and thereby to permit the term to occupy and to serve very different political aims.

She says this however, in relation to 'women' as a concept of 'constitutive 


\section{Johnathan Jodamus}

constraint' (Butler 1993:X), namely, something that has the appearance of necessity and is 'irreducible' (Butler 1993:5). Could something similar be at work with the use of the concept 'Coloured'? Can we do without this concept as a 'constitutive constraint' (Butler 1993:X) and engage with the 'exclusionary operations' that set this term in motion? In implementing the master's tools we should pay due diligence not to become tools of and for the master, which only serves to perpetuate the master's hegemonic ideologies (Conway 2002:182) 23 $^{23}$ It would appear that the seemingly innocent, such as the demand for demographic information like the statistical role call trivia mentioned at the start of this paper, quite often (if not always) signifies governmentality. Depending on who the empowered is, demographic information usually serves the already empowered, as can be also be seen by the Western Cape debacle, where national demographic statistics are deployed to oust 'Coloured' people from provincial and municipal structures, where they are in any case in the majority.

\section{Conclusion}

Theoretically speaking, it appears possible to point the reader to two perspectives or theoretical frameworks that could help us in thinking along the lines of the dissolution of rigid identity(ies), namely queering ${ }^{24}$ and intersectionality $^{25}$. It was exactly these two related frames of reference that catapulted the complexity of identity(ies) onto the dissecting table. The advantage of foregrounding this theoretically is that queering can be 'more' related to gender (whose little block of categorization constitutes a similar problematic to that of race-centric identity markers alluded to in the introduction of this paper), while intersectionality emerged from the plight of

${ }^{23}$ For the notion of 'becoming a tool of the master' see Conway (2008: 182).

${ }^{24}$ Queer theory calls into question fixed notions of gender construction(s) and gender and sex binarism regarded as normative, often implementing such work as Judith Butler's, Gender Trouble: Feminism and the Subversion of Identity ( 1990).

${ }^{25}$ Kimberlé Crenshaw (2011: 25-42) first coined the term intersectionality within the context of critical legal studies and its specific interrogation of the plight and exclusion of 'black women'. 
black women whose 'identity fixedness' as simultaneously black and women disqualified them from legal remedies. Since then this expression has been bolstered and may also be viewed as a critical analytical tool-a 'thinking technology ${ }^{26}$ - that subverts any binary notion of domination and zooms in on the multiplicity and interdependence of social factors that participate in creating and sustaining power relations that function as discourses in the making of normativities, identities and social relations ${ }^{27}$.

Transformation or exploding of essentialist notions of identity(ies) in our South African context, is not something that can happen overnight, just as the inherited notions of identity(ies) with its fixation on race and race-centric ideology(ies) and discourses did not develop overnight, but instead developed over centuries of colonialism and apartheid producing power relations that have concretised in habitus which in turn enables replicated structurings. It should be kept in mind that the structuredness of habitus came into being as the product of reiteration, and its dismantling will similarly come about as a result of reiteration. If identity formation is to be problematised, one should perhaps not only critically scrutinise those relations of power that have produced and benefit by its fixity, but also resist them, fully conscious of the multiplicity of power. Since reiteration has played a constitutive role in the formation of structuredness, this is also the area where 'fissuring' may take place, where the very repetitive may be confronted and made subject to critique. One strategy towards the dissolution of fixed identities would also be the identification of institutional legitimation; institutional such as the academy. Problematisation in this manner prompts towards questioning the ways in which essentialist identity fixation is perpetuated. The notion of 'constitutive constraints' is in this respect very appropriate because it is also from exactly this temporary vantage point that 'colourful' people will be able to launch an attack. In this respect Maluleke is again instructive:

... black theology is not simply all theology done by black people. It is not merely a descriptive category, but one of theological and ideological orientation. Blackness, while including skin color, is construed as much

${ }^{26}$ See Nina Lykke (2011: 207-220).

${ }^{27}$ See Nira Yuval-Davis (2011: 155-169, 159, n.2). See too Kimberlé W. Crenshaw (2011 221-233). 
more than that. It denotes a condition of mind and a specific choice of theological priorities.

We have to realise that the classification and designation 'Coloured', was created through political rhetoric and has a particular history. I maintain that if we continue to use the same constructed classification systems that were enforced upon our grandparents, our mothers and our fathers, we will continue to drink new wine, harvested from the vineyards of democracy, in old wine skins. For us to do this would be tantamount to distorting the new aromas and tastes of this bourgeoning vintage and would instead leave the sour taste and residue of 'pap sak" ${ }^{28}$ in our suckling mouths. I reckon the time has long passed, when our foremothers and fathers were accustomed to drinking 'pap sak' handed down to them as payment for their labour on the 'baas' farm. I want to drink new vintages of democracy in the wine glass of my choice and not from the silver stainless steel 'beeker' that was reserved for the help on 'ou baas se plaas'. Local music artist J.R. delineates the contemporary struggle in his lyrics 'Coloured is ' $\mathrm{n}$ old term [...] is not coloured is colourful $[\ldots]$ make the circle bigger $[\ldots]$ ' Indeed the circle has to be made bigger via new discourses and thinking. The circle out of necessity needs to be made bigger; 'why? Simply kôs 'n mens figure nie mense daai ways yt' (Small 1973).

\section{References}

Appiah, K.A. 2001. African Identities. In Boxill, B. (ed.): Race and Racism. New York: Oxford University Press.

Barker, C. 2002. Television, Globalization and Cultural Identities. Buckingham: Open University Press.

Bourdieu, P. 1990. The Logic of Practice. Cambridge: Polity Press.

Butler, J. 1990. Gender Trouble: Feminism and the Subversion of Identity. London: Routledge.

Butler, J. 1993. Bodies that Matter: On the Discursive Limits of 'Sex'. New York: Routledge.

Butler, J. 2011. Bodies that Matter: On the Discursive Limits of 'Sex'. New York: Routledge.

\footnotetext{
${ }^{28}$ A cheap and poor vintage wine that tastes like sour grapes.
} 
Calhoun, C. 1994. Social Theory and the Politics of Identity. In Calhoun, C. (ed.): Social Theory and the Politics of Identity. Oxford, UK; Cambridge, MA: Blackwell.

Castells, M. 2010. The Power of Identity. Malden, MA: Wiley-Blackwell.

Conway, C.M. 2008. Behold the Man: Jesus and Greco-Roman Masculinity.

Oxford: Oxford University Press.

Crenshaw, K.W. 2011. Demarginalising the Intersection of Race and Sex: A Black Feminist Critique of Anti-Discrimination Doctrine, Feminist

Theory and Anti-Racist Politics. In Vivar, M.T.H. (ed.): Framing Intersectionality: Debates on a Multi-Faceted Concept in Gender Studies.

Ashgate: Surrey and Burlington.

Crenshaw, K.W. 2011. Postscript. In Lutz, H., M.T.H. Vivar \& L. Supik (eds.):

Framing Intersectionality: Debates on a Multi-Faceted Concept in

Gender Studies. Ashgate: Surrey and Burlington.

Csordas, T.J. (ed.) 1994. Embodiment and Experience: The Existential Ground of Culture and Self. New York: Cambridge University Press.

Enloe, C. [1989] 2000. Bananas, Beaches and Bases: Making Feminist Sense of International Politics. Berkley, CA: University of California Press.

Erasmus, Z. \& E. Pieterse 1999. Conceptualising Coloured Identities in the Western Cape Province of South Africa. In Palmberg, M. (ed.): National Identity and Democracy in Africa. Bellville, Cape Town: Capture Press.

Fiorenza, E.S. 2001. Wisdom Ways: Introducing Feminist Biblical Interpretation. Maryknoll: NY: Orbis.

Fiorenza, E.S. 2007. The Power of the Word: Scripture and the Rhetoric of Empire. Minneapolis, MN: Fortress Press.

Foucault, M. 1985. The Use of Pleasure. The History of Sexuality Volume 2. Hurley, R. (trans.). New York, NY: Vintage Books.

Foucault, M. 1986. The Care of the Self. The History of Sexuality Volume 3. Hurley, R. (trans.). New York, NY: Pantheon Books.

Foucault, M. 1991. Nietzsche, Genealogy, History. In Rabinow, P. (ed.): Nietzsche, Genealogy, History. In The Foucault Reader: An Introduction to Foucault's Thought. New York: Penguin Books.

Foucault, M. 1997a. Subjectivity and Truth. In Rabinow, P. (ed.): Subjectivity and Truth. In Michel Foucault: Ethics, Subjectivity and Truth. New York: The New Press.

Foucault, M. 1997b. Technologies of the Self. In Rabinow, P. (ed.): Technologies of the Self. In Michel Foucault: Ethics, Subjectivity and 
Truth. New York: The New Press.

Foucault, M. 1980. Two Lectures. In Gordon, C. (ed.): Power/ Knowledge:

Selected Interviews and Other Writings 1972-1977. New York: Harvester

Wheatsheaf.

Giddens, A. 1991. Modernity and Self-Identity: Self and Society in the Late Modern Age. Stanford, California: Stanford University Press.

Gilroy, P. 2005. Postcolonial Melancholia. New York: NY: Columbia University Press.

Glancy, J.A. 2010. Corporal Knowledge: Early Christian Bodies. Oxford: Oxford University Press.

Lloyd, M. 2005. Beyond Identity Politics: Feminism, Power and Politics. Thousand Oaks, California: Sage Publications.

Lykke, N. 2011. Intersectional Analysis: Black Box or Useful Critical Feminist Thinking Technology. In Vivar, M.T.H. (ed.): Framing Intersectionality: Debates on a Multi-Faceted Concept in Gender Studies. Ashgate: Surrey and Burlington.

Maimela, S.S. 1991. Black Theology and the Quest for a God of Liberation. In Davaney S.G. (ed.): Theology at the End of Modernity: Essays in Honour of Gordon Kaufman. Philadelphia, PA: Trinity Press.

Maluleke, T.S. 1996. Black and African Theologies in the New World Order: A Time to Drink from Our Own Wells. Journal of Theology for Southern Africa 96: 3-19

Maluleke, T.S. 2005. African Theology. In Ford, D. \& R. Muers (eds.): The Modern Theologians: An Introduction to Christian Theology since 1918. $3^{\text {rd }}$ Edition. Oxford: Backwell Publishing Ltd.

Mofokeng, T. 1988. Black Christians, the Bible and Liberation. Journal of Black Theology 2,1: 34-42.

Molthabi, M.G. 1994. Black or African Theology? Toward an Integral African Theology. Journal of Black Theology in South Africa 8,2: 113-41.

Mosala, I.J. 1986. The Use of the Bible in Black Theology. In Mosala I.J. \& B. Tlhagale (eds.): The Unquestionable Right to Be Free. Johannesburg: Skotaville Press; Maryknoll, NY: Orbis Books.

Mosala, I.J. 1989. Biblical Hermeneutics and Black Theology in South Africa. Grand Rapids, MI: Eerdmans.

Perkins, J. 1999. An Ancient Passing Novel: Heliodorous' Aethiopika. Arethusa 32:197-214.

Pui-lan, K. 2005 Postcolonial Imagination \& Feminist Theology. Louisville, 
Kentucky: Westminster John Knox Press.

Scott, J.C. 1990. Domination and the Arts of Resistance: Hidden Transcripts.

New Haven: Conn: Yale University Press.

Small, A. 1973. Oos Wes Tuis Bes: Distrik Ses. Pretoria: Human en Rousseau. Stoler, L.A. 1997. Racial Histories and their Regimes of Truth. Political Power and Social Theory 11: 183-206.

Taylor, R. \& D. Foster. Advancing Non-Racialism in Post Apartheid South Africa. In Palmberg, M. (ed.): National Identity and Democracy in Africa. Bellville, CT: Capture Press.

Thompson, J.B. 1990. Ideology and Modern Culture. Stanford, CA: Stanford University Press.

Tutu, D. 1986. Black Theology and African Theology: Soulmates or Antagonists? In Ferm, D.W. (ed.): Third World Liberation Theologies: A Reader. Maryknoll, NY: Orbis Books.

Wanamaker, C.A. 2003a. By the Power of God: Rhetoric and Ideology in 2 Corinthians 10 - 13. In Gowler, D.B., G.L. Bloomquist \& D.F. Watson (eds.): Fabrics of Discourse: Essays in Honor of Vernon K. Robbins. Harrisburg, PA: Trinity Press.

Wanamaker, C.A. 2003b. A Rhetoric of Power: Ideology and 1 Corinthians 1 - 4. In Burke, T. \& J.K. Elliot (eds.): Paul and the Corinthians: Studies on a Community in Conflict. Essays in Honour of Margaret Thrall. Leiden: Brill.

West, C. \& D.H. Zimmerman. Doing Gender. In Gender: A Sociological Reader. London: Routledge.

Yuval-Davis, N. 2011. Beyond the Recognition and Re-Distribution Dichotomy: Intersectionality and Stratification. In Vivar, M.T.H. (ed.): Framing Intersectionality: Debates on a Multi-Faceted Concept in Gender Studies. Ashgate: Surrey and Burlington.

Johnathan Jodamus New Testament and Gender Studies University of the Western Cape jjodamus@uwc.ac.za 